\title{
A Psychotherapist's Perspective on Victims of Religious Persecution: An Interview with Dr. Fern Waterman
}

\author{
Kathryn Graham
}

\section{Introduction}

As a medical consultant and psychotherapist, Dr. Fern Waterman specializes in massive psychic trauma work with Holocaust survivors and their families, torture victims, abuse, combat and incest survivors. An active member of the Canadian Centre for Victims of Torture, Dr. Waterman does extensive research on victims of persecution (ethnic, racial, religious) and provides counselling to such individuals in her private practice. Hence, her medical and psychotherapeutic background offer fresh, sensitive insights into the accounts highlighted below.

Q1: The abstract term "religious persecution" contains a number of meanings and frequently serves only to blur the complicated psychological processes involved. From a psychiatrist's perspective, would you please explain the processes that occurin both the individual and community psyche?

There is a process which occurs politically that isolate the individual and community being persecuted and how these things are brought into play. But, it does not contend with what happens to the minds of the people being persecuted. We know there is a psychological process that occurs whenever anything traumatic appears. The body and the mind have to adapt when there is no way out.

Kathryn Graham is the Creative Director of MakePeace International. The mission of this creative alliance is to utilize the arts toraise public awareness of global religious persecution and encourage action on behalf of its victims" (Email address: makepeace @glkobalsercve.net).

Dr. Waterman is a senior medical consultant and psychotherapist with the Institute of Family Living in Toronto, Canada. She specializes in massive psychic trauma and works with Holocaust survioors. She is also a member of the advisory council for MakePeace International.
An example of this is the Nazi concentration and death camps. There were many people who saw their whole families butchered or led off to the gas chambers, who did not feel because they knew that they had to survive. It was almost normal to see people being hanged, tortured and beaten. They existed at a vegetativelevel in order to get through the persecution. Others, who did see it and feel it, constantly went mad. Who could in their own right mind accept that? Others, who attempted to talk about it, gradually made the best adjustment. But again, it was so insidious having to suppress all this that what was normal became incredibly abnormal to anyone sane.

There is always a blur. There is always a continuum of how groups and mass psychology work. You can't just say, "Well those Nazi did it!" The fact is what happened was an extreme of what happens in mobs, in groups, in teams. Mob seduction is what we find acceptable. We persecute because we fear that we are going to lose something our children our ideas will be diluted. There is a need for purity. In every orthodox tradition, this fear exists."

Q2: Is the psychiatric world attentive to the cry of the refugee? How do they view human rights and what does it mean to them?

"I think that the spectrum is as broad as the spectrum is for psychiatrists in that, the medical world should be attentive to the cry of the refugees and theoretically, it is on an intellectual level. How we behave as psychiatric community is another matter. Again, not every doctor is a part of The Canadian Centre for Victims of Torture. In essence, we all should be. We should be sensitive to religious and cultural issues since we are a changing society. If we judge people by our standards, we are never going to understand how to help them right now. I am in the process of discovering what channels we have opened for refugees-both political and religious. I am trying to hook up with more official channels that we as mental healthcare givers can say; I see the stress in those patients of mine. But, some of that stress is because they do not know if they are going to be landed immigrants or not." It is wonderful for me to be able to listen to them talk about it. But mere talk is not going to provide the solution. They have to get solid help towards this goal of becoming landed immigrants and being accepted into the community as well as being able to validate themselves economically so that they can bring up their families in some kind of peace and security.

In terms of how the psychiatric world views human rights, I know that the medical schools are being taught something about medical ethics. But, whether it is broadened to look at refugee problems, I am uncertain. I would like to add something in terms of the world medical system. A number of German medical students very recently were interviewed and asked if medical ethics (never mind refugee problems)) should be studied in their medical schools. The students said"no" because they have so much to learn anyway and that would just be something extra. This is a nation that practised the most horrible experiments that you could possibly imagine-more that the world ever knows. I just took a course in Nazi medicine and even $I$ got sick. And I thought I knew everything. Here these medical students said no to being taught medical ethics because it would be too much work. That to me is very frightening. Q3: Do you believe the medical and psychiatric communities are properly educated on the issue of refu-

Refuge, Vol. 19, No. 1 (July 2000) 
gees being persecuted for their faith? If not, how could this problem be rectified?

No. I think that somehow time slots have to be created so that people in the field of mental healthcare, legal profession and grassroots organizations can be brought to talk about the problems so that when doctors or others in the field of mental healthcare run into trouble, there are channels available to access. I have had to find this out by myself. I certainly didn't discover it through any thing I learned in medicine. Remember that this is the social interest aspect of medicine. Medical schools do not teach us about the physiology, structure and function of normal systems and then how they can go awry.

When I practiced a predominant ethnic area like the Jane-Finch corridor, this wasn't offered to me through the family practice unit, which would have been very good entrée for refugee organizations. We just knew that we were servicing a number of people from Portugal, Greece and increasingly from the Muslim countries. But, there was no avenue by which we could get more information. I was simply interested and gathered resources by travelling to their countries and by asking questions. Today, I would be very willing to be asked to come to a medical school and speak about the psychology of persecuted people. The government too has a role to play in rectifying the problem-curriculum and funding.

Q3: Concerning religious persecution, governmentbodies and economic institutions analyse the larger, societal context being affected. A major part of their response is education and information. The psychiatrist however addresses the issue from the "inside out" by attempting to help the refugee rebuild/rediscover meaning and order in his/her life. Politicians and trade organizations do not see the graves of many victims who have died or the scars on the bodies of those who have been tortured for their faith. But, the psychiatrist bears wit- ness to the atrocities, which have taken place through storytelling and memory retrieval of the patient.

Q.4: Share one account of your professional involvement with a refugee case invol-ving religious prosecution. Describe your overall clinical observations? Any personal reactions?

The work I do and the reason I do it is because it has so much meaning for me both as a caregiver and as a mental healthcare worker as well as in a very human, emotional and spiritual sense. My oldest professional involvement with people know the basic horror story of the Holocaust and what they went through.

What are my reactions each time I hear a story? As I am taken through each individual story, the anxiety and panic that they felt, I am drawn into it. The number of sessions where I am exposed to that original story, I always felt personally rubbed raw. I felt more vulnerable at the end of those sessions, particularly top the rest of the world because I know that could have happened to me. But I have always maintained that the day I stop feeling emotion is the day I should quit my profession.

Rebuilding a life trying to restore trust and help a person heal, is often a very long and difficult process. It is one that is not entirely successful because patients continue to have flashbacks and nightmares that we de-finitely try to alleviate by other techniques such as EMDR which helps patients process their terrible memories in a different way. I have accompanied some Holocaust survivors back to Poland to help them face what has tormented them all these decades. The impact is something I will never forget. It will always be with me. Just going back to visit the horror when the people and the actual persecution itself are not there, was terrible enough for me let alone the people that survived it.

I had one patient (a Holocaust survivor) who made a pact with a friend while in the concentration camp that rather than let certain things happen, they would kill themselves. The friend with whom she made this pact one day stood up for her rights to one of the guards. And of course, she was tortured and killed for this act in full view of everyone. The girl, who saw what happened to her teenage friend, was also forced into a very sadistic lesbian relationship by one of the guards at the work camp. And she knew that this was one of the things that were in the pact. And yet, she didn't kill herself. Frankly, I am glad that she didn't because she is a wonderful human being who has brought up several children and delightful grandchildren and has contributed even to the volunteer world. The things she has done for our society doesn't make her death worth it.

Like many Holocaust survivors, this woman lived until after we got back from Poland, with the thought and judgement that somehow she survived because of sinfulness. So until a person forgives his/her own self, that shift to healing isn't made either. When I see forgiveness on those kind of levels: for self, for the perpetrators and for the people who seemed to stand aside and let what happened take place, there is a spiritual shift that is beyond anything I as a therapist can do. I may help promote that process, but the patient or the survivor has to make that final shift. And when they do, to me that is a miracle of the human spirit. That is what makes it all worthwhile.

Q5: How can the psychiatric community provide the national and international organizations a mandate to act (in conjunction with the goodwill not only of politicians, academics, artists, economists and multi-faith groups)?

I believe that what I have been collecting and the kind of material I have been doing with both in information and the sort of processes that are going on in patients, means that $I$ have to step out of my office and do something in the community, national and international setting. The mental health field has to get together and liaison with politicians and other people in power and hopefully get enough 
respect for ourselves that when we say something, it should mean something somewhere in the right circles.

I know there are some organizations that exist, but national and international organizations should be more prominent in that I am still seeing them out for myself."

Q6: The Holocaust witnessed the unprecedented slaughter of European Jews with the intent to exterminate the race, religion and culture of the people. Describe in personal terms, your own family's struggle to escape the Nazi regime, immigrate to Canada and re-assimilate core beliefs (particularly religious).

My own family struggled to escape the Nazi regime actually was precedent of the regime in that they fled to Canada to escape anti-Semitism (which culminated in the Holocaust) and the absolute grinding poverty in which they lived in Poland. They came over in the 30s after Hitler's rise to power. But, they did not foresee the Holocaust as it happened. My grandfather's whole family (with the exception of a handful of people) was murdered in the Holocaust. So we were profoundly affected by it personally and as Jews knowing what happened to our people.

Our family has been having a struggle to come to terms with what happened. I was witness to the guilt that my grandfather lived with because he was unable to get his family over to Canada in time. In subsequent visits back to Poland, I have been able to trace how my relatives were marched to a death camp. That was a horrible and very sad journey for me. But it was important that I find out exactly what happened to them. So we lived in the shadow of the Holocaust almost daily in that, Jews have a tradition of naming their children after relatives who have already died.

My father had many tales to tell of their experiences in Poland. For instance, at Easter time everybody knew that they had to lay low. The Jewish portion of the village didn't come out for a few days because people would stream out of the churches (mostly young men who were thugs anyway)

for Christ killers to beat up.

In terms of re-assimilating our core beliefs, I don't know whether we have comprehended everything. We certainly believe in the tradition of being Jewish and all the moral structure of Judaism. We like to carry on the traditions of Sabbath and kosher. Another point to mention is that I think because we live with the collective unconscious of the Holocaust and everything that proceeded it, a lot of Jews (including myself), live unconsciously with one eye over their shoulder. We are more sensitive to persecution. Yet at the same time, we carry on with our lives not letting it impede us because we all have a task that through God, to become the best we can be.

When Jews came to Canada, they clung tenaciously to the fact that they were Jews and were going to stay that way. But, in order to survive and secure work in a more secular society, many gave up a lot of their traditional practices. Like Maslow's hierarchy, now that mere survival seems to be a problem of the past, we can afford (thanks to democracy) to observe the other rituals. Their meaning has made living Jewishly and spiritually much more meaningful to me.

Q7: In the Old Testament, Jeremiah is a celebrated figure who is referred to as the "weeping prophet" because he was sensitive, tenderhearted and wept over the suffering of his people being carried off into exile. He also warned of denial of saying, "peace, peace" to avoid seeing their problems. Who are the modern day prophets on behalf of today's 23 million refugees? Do they weep over they being persecuted?

Just as Neville Chamberlain said, "peace in our time" Our politicians are doing the same with Kosovo. Who is doing anything bout it? In that respect, I am a modern day prophet because I don't hold with what is being said and only done in a partial wayand that is; I do mourn the innocent people who were killed in the bombings which NATO carried out. But, I am very unhappy with what NATO did because I don't think you should have any truck dealings with the devil. People like Milosevic are monsters. He's a thug. If NATO was really going to get Slobodan to do some kind of giving in, then ground troops should have been sent in. They could have gotten him. Millosevic could be standing in front of the war crimes tribunal today. $\mathrm{He}$ should not be given status in negotiating at all.

If we know anything about human behaviour, then we know that what is going on now is a continuation of what was going on during the Second World War and before Tito. Tito was so charismatic, he suppressed everything. And so everything that wasn't solved before the war and that was going on in the Balkan states, is now continuing with the same hatred and the same kind of primitive thinking. It is primitive thinking that involves collective punishment that seems to be one aspect of why they are pillaging, murdering and cleansing.

An example as to what I think of a prophet comes from a whole other field, not in the human rights arena. But, it is a spiritual sense of how people should behave. And that is through the eyes of a biologist whose name escapes me. I was 16 years old at the time and in first year university taking zoology course. This scientist talked about how our genetic material can be affected by the things in our environment. He emphasized the need to remember that we are the guardians of our genetic material. And how we treat ourselves and the world around us (physically, emotionally and psychologically) will determine what good shape that genetic material will be in. This illustrates my idea of who is a prophet. And if we treat people well, then they won't feel displaced and be forced into exile. They won't be tortured or persecuted for their beliefs, which ties in with the refugee issue.

Refuge, Vol. 19, No. 1 (July 2000) 